\title{
Human and wildlife usage of a protected area buffer zone in an area of high immigration
}

\author{
Andrew J. Bamford, Daniella Ferrol-Schulte and Jennifer Wathan
}

\begin{abstract}
Population growth near protected areas threatens the capacity of such areas for biodiversity conservation. Protected areas may even encourage growth by providing economic benefits that attract migrants. Consequently, understanding the relationships between human demographics and biodiversity is important for conservation. We studied a community-governed Wildlife Management Area bordering the Selous Game Reserve in Tanzania, set up to benefit local people and the subsistence rural economy. Annual population growth in this area is $5 \%$. We used a combination of ecological and socio-economic surveys to determine the causes of this growth and its effect on wildlife in the Wildlife Management Area. One-third of local people interviewed were immigrants to the area. Population growth appeared to be unrelated to the protected area; instead an increasing proportion of immigrants cited readily available land as their reason for moving. Pastoralism was associated with fewer signs of large grazing mammals and elephants Loxodonta africana and agriculture was associated with fewer signs of elephant and buffalo Syncerus caffer but more signs of other ungulates. Few residents were aware of the Wildlife Management Area and few received any benefits from wildlife and therefore had little reason to conserve it. This situation is attributable to poor management of the Wildlife Management Area. Detrimental effects of human activity could spread to the Selous Game Reserve if population growth continues. However, natural resources could benefit residents if properly managed. Interactions between human demographics and protected areas are complex and may be best managed on a case-by-case basis.
\end{abstract}

Keywords Agriculture, burning, cattle, Kilombero, land management plan, protected area, species diversity, Tanzania

This paper contains supplementary material that can be found online at http://journals.cambridge.org

\footnotetext{
ANDREW J. BAmFord* (Corresponding author) DANIELla Ferrol-SChUlte ${ }^{\dagger}$ and JENNIFER WATHAN ${ }^{\ddagger}$ Frontier-Tanzania, P.O. Box 258, Ifakara, Tanzania. E-mail andrew.bamford@wwt.org.uk

*Current address: Wildfowl \& Wetlands Trust, Slimbridge, Gloucestershire, GL2 7BT, UK

${ }^{\dagger}$ Current address: Leibniz Centre for Tropical Marine Ecology (ZMT), Bremen, Germany

${ }^{\ddagger}$ Current address: School of Psychology, University of Sussex, Falmer, UK

Received 28 May 2012. Revision requested 13 August 2012.

Accepted 14 January 2013. First published online 27 January 2014.
}

\section{Introduction}

D rotected areas are a cornerstone of global conservation strategies (Stoner et al., 2007; Gaston et al., 2008) but their effectiveness is threatened by the intensification of land use in surrounding areas, which isolates the protected areas and damages their ecological function (Hansen \& DeFries, 2007). These issues were brought to scientific, political and media attention by Wittemyer et al. (2008), who showed that immigration to the areas immediately surrounding protected areas was higher than the rural mean in many countries in South America and Africa. Although this analysis has been criticized based on the suitability of the datasets used (Joppa et al., 2009), it highlighted the potential damage to protected areas caused by high rates of settlement. Direct damage can be inflicted on a protected area by increases in activities such as timber extraction, hunting and land clearance for agriculture, all of which can have negative effects on wildlife populations (Brashares et al., 2001; Fritz et al., 2003; Metzger et al., 2010; Estes et al., 2012). Indirect damage can also be inflicted by land-use changes outside the protected area that alter the wider ecosystem (Hansen \& DeFries, 2007). Given this potential for detrimental effects there is a need to understand the mechanisms of human migration to protected areas. Wittemyer et al. (2008) hypothesized that local population growth is attributable to the economic benefits derived from investment in protected areas but this idea has also been criticized (Hoffman et al., 2011) because it is unclear whether communities benefit economically from proximity to a protected area (Foerster et al., 2011; Hartter \& Goldman, 2011; Estes et al., 2012). Several alternative models of immigration to protected areas have been proposed (Oglethorpe et al., 2007; Scholte \& De Groot, 2010), including frontier engulfment, whereby a population settles on clear land around the protected area as they move away from more densely populated regions. To clarify the issue more real-world examples of immigration to protected areas are required along with information on the reasons for the immigration and the benefits that may be provided by the protected area, such as income or natural resources.

Forced migration when a protected area is established can lead to displaced and hostile populations living on the protected area boundary (Davis, 2011). Many National Parks and Game Reserves in Tanzania were created in this way and were managed centrally, with few rights awarded to local 
people (Nelson et al., 2007). The Tanzanian government has attempted to rectify this situation by introducing community-managed conservation programmes around the many protected areas. These take the form of Wildlife Management Areas, where village land is set aside for wildlife management and only sustainable use of natural resources is permitted (Songorwa, 1999; Nelson et al., 2007). Many such areas were created as buffer zones to existing protected areas and can contain significant biodiversity (Stoner et al., 2007; Shahabuddin \& Rao, 2010), including charismatic large mammals (Caro, 1999a) that can generate income through tourism (Nelson et al., 2007). These buffers were intended to benefit the community by providing income from natural resources and to benefit the protected areas by reducing poaching and local opposition (Songorwa, 1999; Nelson et al., 2007). By providing economic benefits to communities these schemes can provide the incentives that Wittemyer et al. (2008) hypothesized would cause immigration to an area.

An early example of such a scheme was the Selous Conservation Programme (Songorwa, 1999), started in 1989 by the government of Tanzania. Wildlife Management Areas were established in villages bordering the Selous Game Reserve, the largest protected area in the country. In an effort to reduce poaching, hunting quotas were set and were to be fulfilled by game scouts appointed by village councils, and the scheme was to be funded by the sale of game meat. Although poaching within the Reserve was reduced the community aspect of the programme failed to generate the expected benefits and local people rapidly lost interest (Songorwa, 1999). Unrealistic expectations, perceived high costs and corruption all contributed to the failure of the programme (Songorwa, 1999). It was not replaced by an alternative and many of the landmanagement plans remain in place. Community wildlife management programmes elsewhere have since been refined but still attract criticism, not least because the management of wildlife resources has become more centralized (Nelson et al., 2007). Nonetheless community conservation schemes can work if managed correctly.

Involvement of local stakeholders is essential for effective natural resource management (Ostrom, 1990; BorriniFeyerabend, 2011), especially when it comes to allocating rights, responsibilities and access to land and resources (Sen, 1983). In rural areas in developing countries participatory land-use planning has been used to mitigate human-wildlife conflict, protect ecosystems from overexploitation and as guidance for sustainable livelihoods in natural-resource dependent communities (ValenciaSandoval et al., 2010). Engaging communities to participate in land-use planning depends on entrenched attitudes to wildlife as well as the perceived benefits of land-use plans that incorporate environmental protection (Songorwa, 1999). The perceived benefits of protection must exceed the benefits of non-protection (Ostrom, 1990; Songorwa, 1999; Hemson et al., 2009), otherwise a negative attitude to conservation measures can result (Sarker \& Røscaft, 2011). For example, although income from hunting and photographic safaris in Tanzania can be substantial (Nelson et al., 2007), the industry is often managed by foreign companies granted concessions to operate on set blocks of land, and profits go to the national government rather than the local communities. Officially, $25 \%$ of this income should be returned to the communities but this often does not happen (Nelson et al., 2007). Contractual schemes in which money is paid directly to communities are more often successful (Sachedina \& Nelson, 2010).

There is little information on how communities use the natural resources in the areas they have been allocated to manage, or on the effects that human activity may have on the wildlife in these areas. Assessing wildlife abundance in snapshots can be misleading as large mammals are not always resident in an area year-round (Stoner et al., 2007). To fully understand these issues humans and wildlife must be studied together over a prolonged period of time. Here we present a case study of a Wildlife Management Area on the boundary of the Selous Game Reserve, in a region that is undergoing annual population growth of $5 \%$ (Alba et al., 2010). We used a combination of interviews and wildlife transects to assess the effect of immigration on the protected area. Our objectives were to investigate the causes of the immigration, the livelihoods of people living in proximity to the Wildlife Management Area, the presence of large mammals and whether they are resident or migratory, the benefits of the protected area in terms of income or resources, opinions on natural resource management, and the effect of human activity on wildlife.

\section{Study area}

The Kilombero Valley in southern Tanzania is the largest wetland in East Africa. It is a BirdLife Important Bird Area and a Ramsar site. It is home to several endemic bird species as well as $75 \%$ of the remaining puku Kobus vardoni in Africa (Hinde et al., 2001; Haule et al., 2002; Jenkins et al., 2002). The valley consists of a fertile seasonal floodplain fringed by miombo woodland (Kato, 2007) and there has been a significant increase in agriculture in the area since 2003 (Kato, 2007). The rainy season spans November-May but the majority of the rain falls at the end of the season (Kato, 2007). Historically the dominant tribal groups in this area (Pogoro and Ndamba) were agriculturalists and did not keep cattle; cows only arrived with the immigration of predominantly Sukuma pastoralists from the north of Tanzania in the last decade. The Kilombero Valley is split into two administrative districts; this study was conducted 


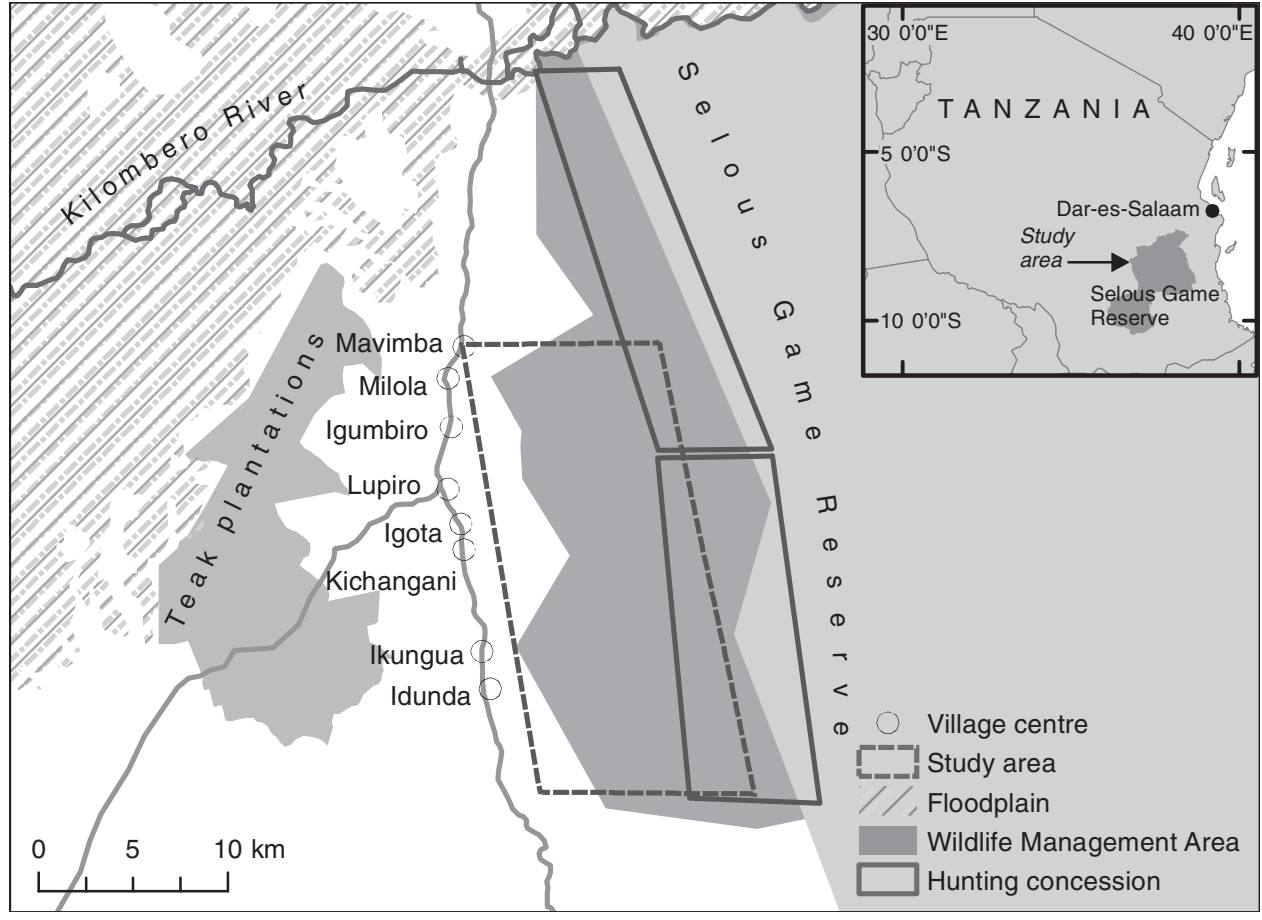

FIg. 1 The study area in the Kilombero Valley, Tanzania, showing the communitygoverned Wildlife Management Area and the villages included in the study. The arrow on the inset indicates the location of the main map in Tanzania. in Ulanga District, which covers the southern half of the valley and borders the Selous Game Reserve (Fig. 1).

Despite the perceived failure of the Selous Conservation Programme a similar project was started in Ulanga District in 1996, funded by the African Development Bank. Landmanagement plans were written for 10 of the 11 villages in the district that border the Selous, creating a Wildlife Management Area $\left(880 \mathrm{~km}^{2}\right)$ as a buffer zone. These plans also designated large areas of land for commercial teak plantations. Our study area consisted of the most southern eight of these villages.

The villages lie along the road between the towns of Ifakara and Mahenge, which runs along the edge of the Kilombero floodplain (Fig. 1). East of the road is a mosaic of grassland and miombo woodland. The Wildlife Management Area starts c. $7 \mathrm{~km}$ east of the road and the boundary of the Selous Game Reserve is $20 \mathrm{~km}$ east of the road. Directly outside the Reserve the land is managed for recreational hunting. Hunting in the concessions and Wildlife Management Area is only permitted during JulyDecember.

Annual population growth in the Kilombero Valley was 5\% during 2004-2008 (Alba et al., 2010), confirming the suggestion of Wittemyer et al. (2008) that high immigration occurs close to protected areas. According to figures given to us by the village councils (from the 2002 national census; National Bureau of Statistics, 2012) the total population of the eight villages in the study area was 18,716 . The total area covered by the land-management plans is $855 \mathrm{~km}^{2}$, of which $70 \%$ is set aside for wildlife management.

\section{Methods}

\section{Socio-economic data collection}

To investigate livelihoods, the causes of immigration and usage of plant and wildlife resources we conducted interviews with 274 households during February-August 2010. We used a stratified opportunity sample (Bryman, 2012) to select interviewees and surveyed approximately the same number of households in each village. For the sampling unit we defined a household as a group of people living together and sharing economic resources. One member of each household was interviewed by a native Swahili speaker, with one of the researchers present. The structured interviews (Supplementary Material 1) lasted c. 30 minutes and consisted of both closed and open-ended questions. If a respondent gave more than one answer to an openended question they were asked to select the most important.

We also interviewed representatives of the eight village councils and Ulanga District Council. Village councils were represented by the chairman, the executive officer, or both. In the District Council we interviewed the District Wildlife Officer and District Forestry Officer. Interviews, again conducted by a native Swahili speaker in the presence of one of the researchers, were semi-structured and covered population increase, human-wildlife interactions, landmanagement plans and the planning process (focusing on the degree of village-level participation, information dissemination and implementation). 


\section{Ecological data collection}

To investigate which large mammal species were present and at what times of year, and the effect of human activities on those species, we monitored 24 transects, each $500 \mathrm{~m}$ in length, randomly placed within an area 7-14 km east of the main road. This area comprises land that is within the Wildlife Management Area but not within the hunting blocks. We surveyed each transect once in every 3-month period during 2008-2010. To determine the extent of human activity outside the Wildlife Management Area we surveyed 10 additional transects between the road and the edge of the Wildlife Management Area in 2010. All signs of large and medium mammals (the smallest mammals included were mongooses (Herpestidae) and cane rats Thryonomys swinderianus; signs included tracks and faeces) detected in a $2 \mathrm{~m}$ strip along the transect were recorded. By recording spoor rather than animal sightings we were able to record more species and give better estimates of species diversity (Silveira et al., 2003; Cromsigt et al., 2008), as sightings of animals in forested and human-disturbed landscapes are infrequent (Caro 1999b; Jenkins et al., 2002). We used strip transects in preference to Distance sampling because a component of our project was to train local people to undertake biodiversity monitoring and ultimately to take over responsibility for the monitoring. Therefore, we required a method of analysis that did not require computers to provide a usable index of large mammal activity. Additionally, strip transects are less likely to result in different detectability of signs between different habitat types.

Transects were divided into 20-m sections and tracks present in each section were recorded. To standardize data collection one trained game guard was always present to aid identification. For each transect we recorded a track score (the number of transect sections (out of 25) in which tracks were located) and a count of dung piles. Recording track data increases the likelihood of detecting a species but does not necessarily provide information on abundance (it is related to both abundance and activity levels; Jenkins et al., 2002) whereas dung counts are useful as estimates of abundance (Plumptre, 2000; Cromsigt et al., 2008) but only if sample sizes are large enough.

The extent of farming in the survey area was quantified as percentage land cover, using a combination of global positioning system mapping (conducted throughout 2010), where farms occurred at low density, and examination of Google Earth images (Google, 2011). We plotted land cover in ArcMap v.10 (ESRI, Redlands, USA). Cows detected on transects were given a track score as for other large mammals. The area burned was quantified as percentage ground cover, recorded in $5 \times 5 \mathrm{~m}$ quadrats at the end of each transect section, and a mean value was calculated for each transect.

\section{Statistical analyses}

All analyses of transect data were carried out in $R v$. 2.14.1 (R Development Core Team, 2012), using lme4. The unit of replication was a single $500 \mathrm{~m}$ transect. For analysis of temporal trends we used dung counts as the response variable in a log-linear mixed-effects model. The survey number was included as an explanatory variable and transect number as a random effect, to account for repeatedly surveying the same transects, which is a statistically powerful way of monitoring changes in abundance (Plumptre, 2000). Survey numbers were aggregated to minimize the model's Akaike Information Criterion.

To analyse the effect of human activity on large mammals we used track and dung count data along with information on locations of farms, presence of cattle and the extent of burning. Three approaches were taken. Where dung counts for a species were large enough we used loglinear models, with the dung count as the response variable. For track data we used a logistical model in which the response variable was the number of sections (out of 25) on which tracks were recorded. Finally, for species where dung counts and track counts were too low for satisfactory analysis we used a simple presence/absence approach in a logistical model, the response variable being either 1 (species present on that transect) or o (species not present). For some species more than one method could be used, allowing comparison of results between methods. In all models transect number and survey number were fitted as random effects. As each transect was only surveyed once per survey, each observation was fitted with an independent intercept. Three explanatory variables were considered: the distance to the nearest farm, the track score for cows and the proportion of burnt ground. In each case we selected the model with the lowest AIC.

\section{Results}

\section{Immigration}

Almost a third of respondents $(32 \%, \mathrm{n}=274)$ were immigrants to the study area and $10.2 \%$ had migrated to the area within the previous year (Table 1). Sixty-one percent of pastoralists in the area $(n=18)$ had moved there within the previous year (Table 1 ). The most commonly reported reasons for moving to the area were family reasons (47.6\%), including marriage, to acquire land (35.7\%) and for work (10.7\%). The number of people immigrating for family reasons appears constant over time, whereas the number immigrating to acquire land appears to be increasing (Table 1).

Interviews revealed that all eight village councils were unsure of the exact populations of their villages. The decadal national census had not been completed effectively in the 
TABle 1 The length of time survey respondents had lived in the study area (Fig. 1), the type of agriculture used, and their reason for migrating.

\begin{tabular}{|c|c|c|c|c|c|}
\hline & \multicolumn{5}{|c|}{ Duration of residency } \\
\hline & $<1$ year & $1-5$ years & $5-10$ years & $>10$ years & Lifetime \\
\hline \multicolumn{6}{|c|}{ Type of agriculture } \\
\hline Crop cultivation & 17 & 18 & 9 & 26 & 187 \\
\hline Pastoralism & 11 & 3 & 0 & 4 & 0 \\
\hline \multicolumn{6}{|c|}{ Reason for moving to study area } \\
\hline Land & 16 & 8 & 2 & 6 & \\
\hline Family & 8 & 8 & 8 & 16 & \\
\hline Job & 2 & 2 & 0 & 5 & \\
\hline Other & 0 & 1 & 2 & 0 & \\
\hline
\end{tabular}

District and the level of immigration was unknown because village councils did not have the capacity to monitor settlement on their land. Likewise, the District Council lacked the resources to control immigration.

\section{Livelihoods and natural resource management}

Every respondent owned a farm (median size 3 ha, range $0.25-50$ ha). Only $12 \%$ stated that they, or another member of the household, had alternative employment and a further $5 \%$ regularly received money from relatives. All other respondents were entirely dependent on their farms for subsistence. Farm labouring and selling crops were the most common income-generating activities and were generally done as needed to cover cash demands such as school fees or hospital expenses.

All the villages had land-management plans but only $10 \%$ of interviewees were aware of these. All eight village councils said that these plans were created to set aside land for teak plantations; none mentioned the Selous buffer zone. The village councils had not been consulted about the plans. Five councils stated that they had not seen the plans before implementation and that village boundaries were set without consultation. Three villages were engaged in disputes over compensation for land set aside for plantations. All eight councils stated they did not hunt and that this was done by the District Council. They also stated that they had not received game meat from the District Council for a number of years (2-4) and were unsure why this had stopped. According to the District Wildlife Officer the villages did not receive game meat because they failed to meet their obligations to protect the Wildlife Management Area.

Natural resources were considered important by the majority of respondents (78\%) but wildlife specifically was considered important by only $20 \%$. Nearly all respondents (97\%) reported collecting plant material for construction, firewood or medicinal purposes and $61 \%$ collected at least some of this from the Wildlife Management Area. No respondents admitted to hunting. The number of snares discovered on transects in the Wildlife Management Area (eight in 2010) was too small for analysis. Large mammals were cited as the cause of crop losses, with bushpig Potamochoerus larvatus (35\%), baboon Papio sp. (21\%) and elephant Loxodonta africana (17\%) blamed most frequently.

Most respondents (76\%) stated that the area around their farm was burned every year but $54 \%$ did not know why. Reasons cited by other respondents were land clearance $(19 \%)$, creating grazing for cattle (14\%), and hunting (10\%).

\section{Large mammals and the effect of human disturbance}

Twenty-nine species of large mammal (plus cows) were recorded over 3 years of monitoring (Supplementary Table 1), four of which were recorded only once. Nine species of antelope were recorded. Elephants and buffalo Syncerus caffer were the two most frequently recorded species. Species richness $\left(r_{s}=0.819, P=0.001\right)$ and diversity $\left(r_{s}=0.74, P=0.008\right)$ declined over 3 years.

There were four species for which dung counts were sufficient to estimate abundance. The abundance of buffalo and waterbuck Kobus ellipsiprymnus was consistent throughout the year. Dung counts for both species were negatively associated with rainfall and were low in the April-June survey, when rainfall was highest, but this may be attributable to more rapid decay of dung in the rain. Elephant and duiker Cephalophini spp. abundance peaked in July-September and October-December, respectively (Fig. 2); neither species appears to be resident year-round.

Encroachment into the Wildlife Management Area was low at the time of the study (Fig. 3) but adjacent land was filling rapidly. Burnt ground was recorded only in the October-December transect survey each year, during the dry season. Human activities were found to influence the spatial distribution of large mammal spoor (Table 2). In places where cows were present we found less evidence of several species of large-bodied grazing antelopes and of elephants but not of any browsing species (Table 2). Conversely, close to farms we found more evidence of 

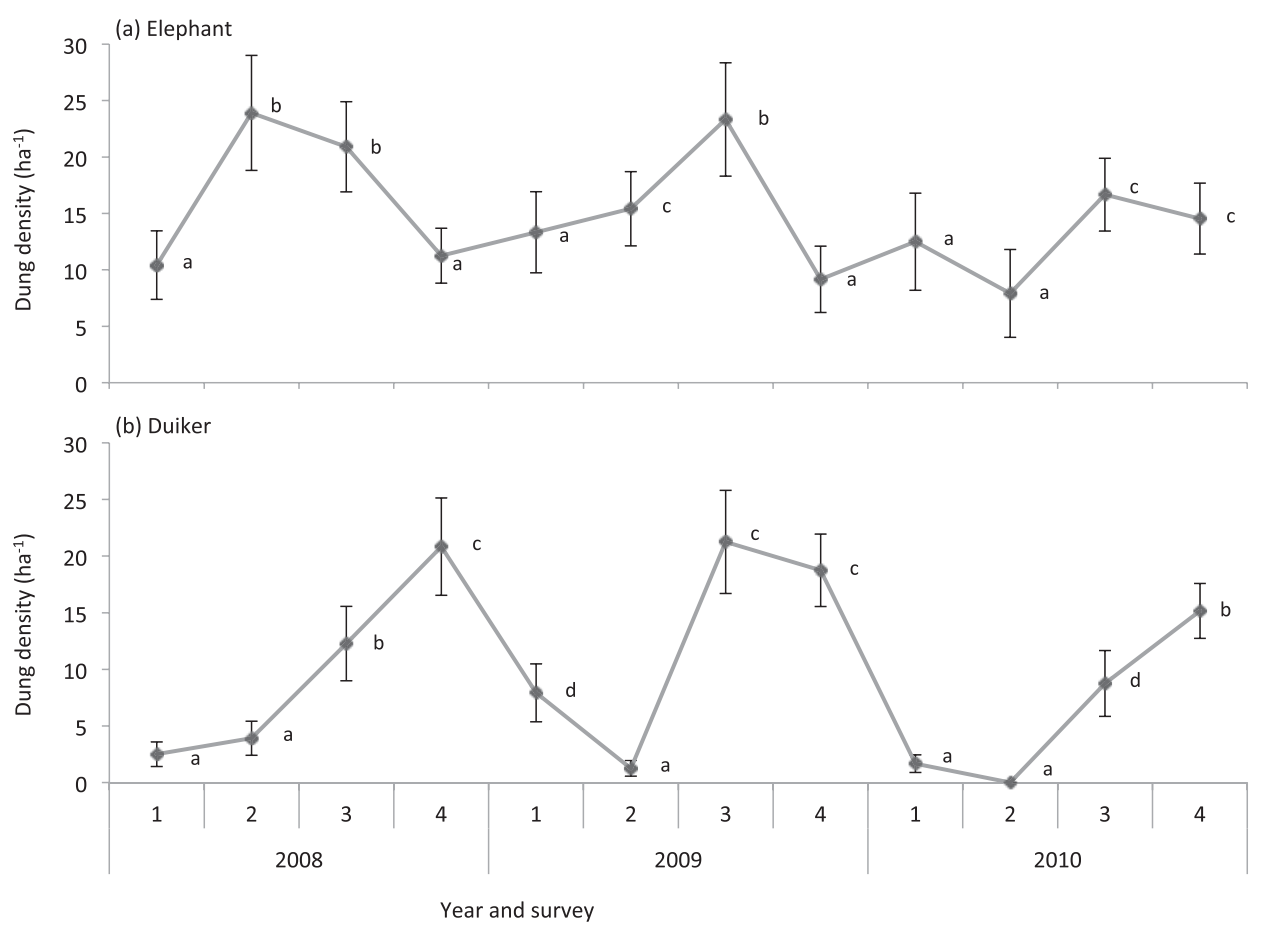

FIG. 2 Dung density of (a) elephant Loxodonta africana and (b) duiker Cephalophini spp.. Error bars represent \pm 1 SE. Letters next to data points indicate statistical differences: surveys with the same letter were aggregated to produce the model with the lowest AIC value. Surveys 1 and 2 were carried out in the rainy season each year.

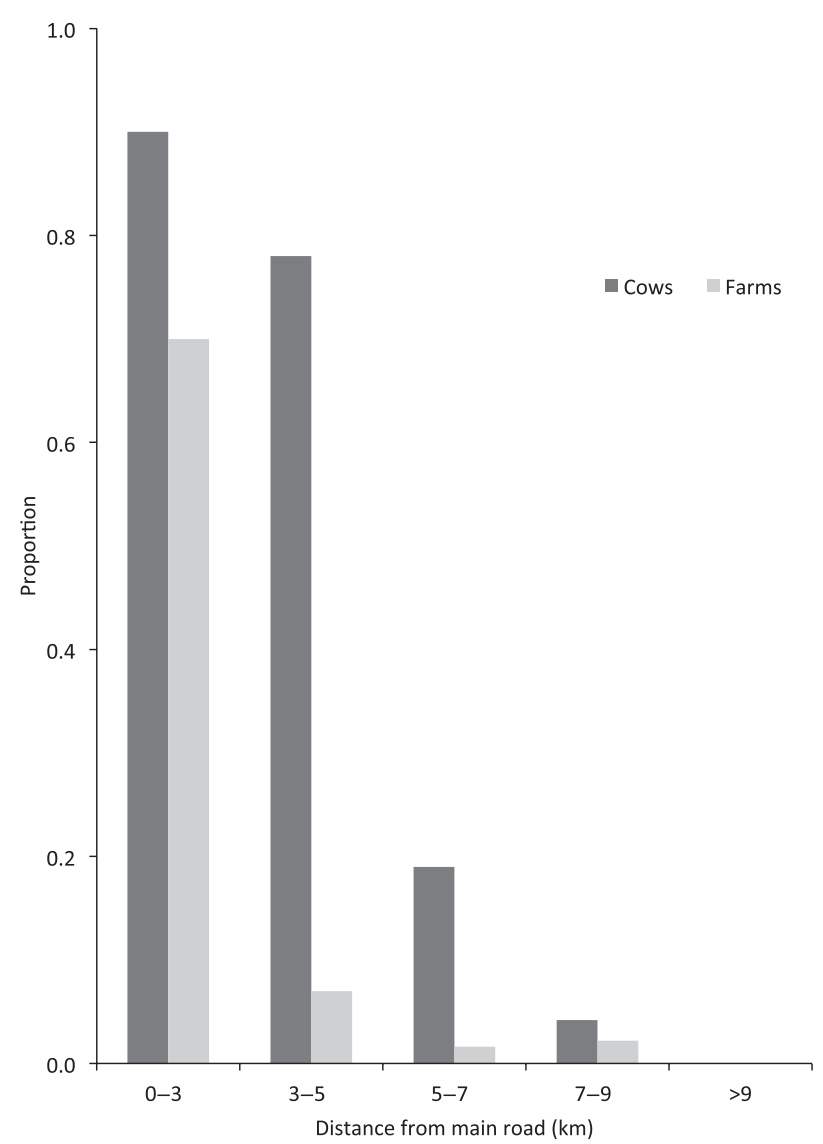

FIG. 3 Human activity (proportion of land area covered by farms and proportion of transect sections on which cow tracks were detected) in the study area in relation to distance from the main road. The road runs north-south, c. $7 \mathrm{~km}$ west of the buffer zone boundary. many species, mostly grazers but also sable Hippotragus niger and warthog Phacochoerus africanus. Two exceptions were elephant and buffalo, for which we detected less evidence close to farms (Table 2). There was more evidence of buffalo, reedbuck Redunca spp. and duiker in burnt areas and no species was less likely to be found in burnt areas than in other areas. The different methods of analysis yielded qualitatively consistent results.

\section{Discussion}

\section{Immigration}

Immigration to the area appears to be increasing. In the 1990 immigration rates were low; a survey in 1997 revealed that only $3.5 \%$ of 228 respondents were first-generation immigrants (Starkey et al., 2002). Contrary to the hypothesis of Wittemyer et al. (2008) we found no evidence that the increased immigration is attributable to benefits from the protected area. The availability of land was the main motivation for migration in recent years.

This could be perceived as migration to an economic opportunity, particularly because the land of the Kilombero Valley is fertile (Kato, 2007), but the opportunity is unrelated to the presence of the protected area. The immigration fits the frontier engulfment model of Scholte \& De Groot (2010), whereby migrants move away from densely populated regions onto available land. The land surrounding the Selous Game Reserve was historically sparsely populated primarily because of disease. The forced 
TABLE 2 The effect of human disturbance on species of large mammal, with the type of spoor surveyed, whether farms, cows, and burning had positive or negative effects, and AIC values. For dung samples we used a log-linear regression of dung counts; for tracks we used a logistic regression in which the response was the number of transect sections (out of 25) in which tracks of that species were detected; for presence data we used a binomial regression in which the response equals 1 if any sign of that species was found on a transect. In all models transect number and survey number were included as random effects. The model with the lowest AIC (Akaike's information criterion) was selected in each case. + indicates a positive effect, - a negative effect.

\begin{tabular}{|c|c|c|c|c|c|c|c|}
\hline Species & Spoor & Farms & Cows & Burning & AIC final & AIC all & AIC null \\
\hline \multicolumn{8}{|l|}{ Grazers } \\
\hline \multirow[t]{2}{*}{ Buffalo Syncerus caffer } & Dung & & - & & 417.5 & 419.6 & 420.4 \\
\hline & Tracks & $-* * *$ & $-* * *$ & $t^{* *}$ & 958.0 & 958.0 & 988.4 \\
\hline \multirow[t]{2}{*}{ Waterbuck Kobus ellipsiprymnus } & Dung & $t^{* * *}$ & - & & 374.3 & 375.8 & 386.3 \\
\hline & Tracks & $+* * *$ & $-* * *$ & & 883.0 & 883.1 & 935.8 \\
\hline \multirow{3}{*}{ Reedbuck Redunca spp. } & Dung & + & & $t^{* * *}$ & 221.2 & 223.1 & 230.3 \\
\hline & Tracks & $t^{* * *}$ & - & + & 530.9 & 530.9 & 547.2 \\
\hline & Presence & $t^{* * *}$ & & & 381.9 & 385.1 & 403.0 \\
\hline \multirow[t]{2}{*}{ Hartebeest Alcelaphus buselaphus } & Tracks & $t^{* * *}$ & $-{ }^{* *}$ & & 476.9 & 538.8 & 539.0 \\
\hline & Presence & $t^{* * *}$ & $--^{* *}$ & & 322.2 & 321.6 & 378.3 \\
\hline Zebra Equus quagga & Presence & $t^{* * *}$ & & & 247.9 & 294.6 & 337.9 \\
\hline \multicolumn{8}{|l|}{ Browsers } \\
\hline \multirow{2}{*}{ Duiker Cephalophini spp. } & Dung & & & $+^{* * *}$ & 437.0 & 437.0 & 474.1 \\
\hline & Tracks & & & + & 883.0 & 883.2 & 884.0 \\
\hline Bushbuck Tragelaphus scriptus & Presence & & & & 355.8 & 358.5 & 355.8 \\
\hline Sable Hippotragus niger & Presence & $t^{* * *}$ & $-{ }^{* *}$ & & 288.7 & 290.7 & 326.7 \\
\hline Eland Taurotragus oryx & Presence & & & & 324.4 & 326.8 & 324.4 \\
\hline \multirow[t]{2}{*}{ Elephant Loxodonta africana } & Dung & $-* * *$ & - & & 483.0 & 484.3 & 543.7 \\
\hline & Tracks & $-* * *$ & $-* * *$ & & 970.3 & 971.2 & 1033.0 \\
\hline Bushpig Potamochoerus larvatus & Tracks & - & $-{ }^{* *}$ & $+^{*}$ & 897.5 & 897.5 & 909.4 \\
\hline \multirow[t]{2}{*}{ Warthog Phacochoerus africanus } & Tracks & $+* * *$ & & & 538.1 & 541.1 & 559.4 \\
\hline & Presence & $+* * *$ & & & 394.9 & 397.0 & 408.1 \\
\hline
\end{tabular}

${ }^{*} \mathrm{P} \leqslant 0.05,{ }^{* *} \mathrm{P} \leqslant 0.01,{ }^{* *} \mathrm{P} \leqslant 0.001$

migrations that cleared the land of people in the colonial era resulted in increased wildlife populations. A corresponding rise in tsetse fly numbers and the prevalence of sleeping sickness kept the land clear of people (Fjeldså et al., 2004). Efforts to reduce the incidence of this disease since 2001 (Hotez \& Kamath, 2009) have inadvertently facilitated uncontrolled migration into the Kilombero Valley. There are few authoritative obstacles to settlement or expansion of farms and the area of land used for agriculture is expanding (Kato, 2007).

Immigration to the area surrounding the Serengeti ecosystem in northern Tanzania has also been attributed to the availability of land for agriculture in a subsistence economy (Estes et al., 2012). Thus there is no evidence linking migration to two of Tanzania's largest conservation areas with economic benefits relating to conservation, and land conversion may have detrimental effects on the protected areas (Hansen \& DeFries, 2007).

\section{Effects of human activity on wildlife}

We observed detrimental effects of agriculture, pastoralism, burning and hunting on wildlife despite low levels of human activity within the Wildlife Management Area, although some positive effects were also observed. The presence of cows was associated with fewer signs of several species, which is of particular concern given the increase in immigration by pastoralists. In contrast, burning was associated with increased signs of several species, including duiker. However, a major aim of burning is to generate new plant growth for grazing by cattle. We detected signs of illegal hunting, including snares and gunshots, in the Wildlife Management Area but they were too infrequent to analyse. No one questioned admitted to hunting and most hunting in the area was probably within the quotas set when the buffer was established.

Agriculture was associated with more signs of some species but fewer signs of others, notably elephants. This part of the Kilombero Valley is thought to be an important elephant migration route (Jones et al., 2012) and our results confirm that elephants use the Wildlife Management Area on a seasonal basis. The negative influence of both pastoralism and agriculture on elephant distribution may be because farmers regard elephants as problem animals and chase them away from their land. Elephants generally pass through human-disturbed areas quickly, leaving few signs (Douglas-Hamilton et al., 2005), but facilitating this 
movement without exacerbating human-wildlife conflict requires careful planning.

Although the level of human activity within the Wildlife Management Area was low at the time of our study the agricultural frontier is extending into the area and it is becoming apparent that there are no effective mechanisms in place to stop this. The detrimental effects will be exacerbated by increasing human population density (Brashares et al., 2001; Hansen \& DeFries, 2007) and the Wildlife Management Area will become degraded. In the longer term the Selous Game Reserve itself may be affected. At this relatively early stage of encroachment effective conservation should be possible (DeFries et al., 2007; Scholte \& de Groot, 2009) but the land-management plans do not appear to have been designed or implemented well enough to ensure this.

\section{Natural resource management}

A majority of residents were not aware of land-management plans that had been in place for over a decade. Village councils were unhappy with the process that led to the creation of the plans, claiming they were not consulted. The plans had two separate aims, the creation of the Wildlife Management Area and the creation of the teak plantations, both of which resulted in large losses of land for local people and from which they perceive few benefits. Our results suggest that the only benefits the local people receive from the Wildlife Management Area come from collection of limited natural resources, mainly wood and medicinal plants. They receive no income and no game meat. The presence of foreign-owned hunting companies is seen as a further imposition, as the villages receive no share of the hunting income (a common problem in Tanzania; Nelson et al., 2007). The hunting companies deny that they are on village land and therefore claim that they are not legally obliged to support village development (Sachedina \& Nelson, 2010). Although local people receive compensation for loss of land to the teak plantations, they regard the payment as unfair because it is not commensurate with the area of land lost. As this is an area with a subsistence economy, land ownership is an important issue and there is a perception that village land has been stolen by foreign companies.

Our findings reiterate the importance of involving local stakeholders in natural resource management planning (Borrini-Feyerabend, 2011) and the dissatisfaction that arises in communities when the perceived benefits of conservation schemes are inadequate (Sarker \& Røscaft, 2011). Even where rural land-use planning is truly participatory (Mathbor, 2008) the quality of the plans and their successful implementation can pose significant challenges in achieving conservation and development aims (Songorwa, 1999;
Masalu, 2000; Bourgoin, 2012). In the case of our study site it is still possible to resolve these issues before the agricultural frontier encroaches heavily on the Wildlife Management Area (DeFries et al., 2007). The positive effects of agriculture on some wildlife suggest the possibility of mixed-use areas to increase the land available for farming but this may exacerbate human-wildlife conflict (Estes et al., 2012) and it remains to be seen if these positive effects still occur when the density of farming is higher (Fritz et al., 2003). Instead, reducing dependence on subsistence agriculture may be helpful. The abundant wildlife in the Wildlife Management Area could be the basis for sustainable tourism if the necessary infrastructure could be built, and this could provide jobs and income for local people (Nelson et al., 2007; Sachedina \& Nelson, 2010).

\section{Acknowledgements}

We thank the respondents to our questionnaire for their time and insights, Nizar Kilale, Sebastian Ngasoma and Hillary Smith for administering the questionnaires, Kara Schroepfer, Peter Msangameno, Jacob Ndimbo, Aroni Mtutui, Chloë Haigh, Billy Fairburn and Steph Fuchs for help with the ecological surveys, and the numerous volunteers and staff working for Frontier-Tanzania who assisted with the fieldwork. Ulanga District Council and various village councils gave us permission to work on their land and answered our questions. Frontier-Tanzania is a collaboration between the Society for Environmental Exploration and the University of Dar-es-Salaam. We thank Flora Ismail and Flora Magige for their support. Bob Smith and two anonymous reviewers provided detailed comments on this article. This study was funded by the Darwin Initiative (project ref. 17028).

\section{References}

Alba, S., Hetzel, M.W., Nathan, R., Alexander, M. \& LeNGeler, C. (2010) Assessing the impact of malaria interventions on morbidity through a community-based surveillance system. International Journal of Epidemiology, 40, 405-416.

Borrini-Feyerabend, G. (2011) Co-management and shared governance-the 'effective and equitable option' for natural resources and protected areas? In Proceedings of the National Workshop on Co-management Concept and Practice in Viet Nam Soc Trang, 17-19 March 2010 (eds D.G. Spelchan, I.A. Nicoll \& N.T.P. Hao), pp. 5-25. GIZ GmBH, Bonn, Germany.

Bourgoin, J. (2012) Sharpening an understanding of socio-ecological landscapes in participatory land-use planning: a case study in Lao PDR. Applied Geography, 34, 99-110.

Brashares, J.S., Arcese, P. \& SAm, M.K. (2001) Human demography and reserve size predict wildlife extinction in West Africa.

Proceedings of the Royal Society B, 268, 2473-2478.

Bryman, A. (2012) Social Research Methods, 4th edition. Oxford University Press, Oxford, UK. 
Caro, T.M. (1999a) Densities of mammals in partially protected areas: the Katavi ecosystem of western Tanzania. Journal of Applied Ecology, 36, 205-217.

Caro, T.M. (1999b) Behaviour and demography of African mammals subject to exploitation. Biological Conservation, 91, 91-97.

Cromsigt, J.P.G.M., van Rensburg, S.J., Etienne, R.S. \& Olff, H (2008) Monitoring large herbivore diversity at different scales: comparing direct and indirect methods. Biodiversity and Conservation, 18, 1219-1231.

Davis, A. (2011) 'Ha! What is the benefit of living next to the park?' Factors limiting in-migration next to Tarangire National Park, Tanzania. Conservation \& Society, 9, 25-34.

DeFries, R., Hansen, A., Turner, B.L., Reid, R. \& Liu, J. (2007) Land use change around protected areas: management to balance human needs and ecological function. Ecological Applications, 17, 1031-1038.

Douglas-Hamilton, I., Krink, T. \& Vollrath, F. (2005) Movements and corridors of African elephants in relation to protected areas. Naturwissenschaften, 92, 158-163.

Estes, A.B., Kuemmerle, T., Kushnir, H., Radeloff, V.C. \& Shugart, H.H. (2012) Land-cover change and human population trends in the greater Serengeti ecosystem from 1984-2003. Biological Conservation, $147,255-263$.

FJeldsÅ, J., Burgess, N.D., Blyth, S. \& de Klerk, H.M. (2004) What are the major gaps in the reserve network for Africa's mammals? Oryx, 38, 17-25.

Foerster, S., Wilkie, D.S., Morelli, G.A., Demmer, J., Starkey, M., Telfer, P. \& S Teil, M. (2011) Human livelihoods and protected areas in Gabon: a cross-sectional comparison of welfare and consumption patterns. Oryx, 45, 347-356.

Fritz, H., Said, S., Renaud, P-C., Mutake, S., Coid, C. \& Monicat, F. (2003) The effects of agricultural fields and human settlements on the use of rivers by wildlife in the mid-Zambezi valley, Zimbabwe. Landscape Ecology, 18, 293-302.

Gaston, K.J., Jackson, S.F., Cantú-Salazar, L. \& CruzPIÑón, G. (2008) The ecological performance of protected areas. Annual Review of Ecology, Evolution, and Systematics, 39, 93-113.

Google (2011) Google Earth v.7, SPOT image of Ifakara area: 8.516 N, 36.8575 E [accessed 1 June 2011].

Hansen, A.J. \& DeFries, R. (2007) Ecological mechanisms linking protected areas to surrounding lands. Ecological Applications, 17, 974-988.

Hartter, J. \& Goldman, A. (2011) Local responses to a forest park in western Uganda: alternative narratives on fortress conservation. Oryx, 45, 60-68.

Haule, K.S., Johnsen, F.H. \& Maganga, S.L.S. (2002) Striving for sustainable wildlife management: the case of the Kilombero Game Controlled Area, Tanzania. Journal of Environmental Management, $66,31-42$.

Hemson, G., Malennon, S., Mills, G., Johnson, P. \& Macdonald, D. (2009) Community, lions, livestock and money: a spatial and social analysis of attitudes to wildlife and the conservation value of tourism in a human-carnivore conflict in Botswana. Biological Conservation, 142, 2718-2725.

Hinde, R.J., Corti, G.R., Fanning, E. \& Jenkins, R.K.B. (2001) Large mammals in miombo woodland, evergreen forest and a young teak (Tectona grandis) plantation in the Kilombero Valley, Tanzania. African Journal of Ecology, 39, 318-321.

Hoffman, D.M., FAY, D. \& Joppa, L. (2011) Human migration to protected area edges in Africa and Latin America: questioning large-scale statistical analysis. Conservation \& Society, $9,1-7$.
Hotez, P.J. \& Kamath, A. (2009) Neglected tropical diseases in sub-Saharan Africa: review of their prevalence, distribution and disease burden. PLoS Neglected Tropical Disease, 3, e412.

Jenkins, R.K.B., Corti, G.R., Fanning, E. \& Roettcher, K. (2002) Management implications of antelope habitat use in the Kilombero Valley, Tanzania. Oryx, 36, 161-169.

Jones, T., Bamford, A.J., Ferrol-Schulte, D., Hieronimo, P., McWilliam, N. \& Rovero, F. (2012) Vanishing wildlife corridors and options for restoration: a case study from Tanzania. Tropical Conservation Science, 5, 463-474.

Joppa, L.N., LoArie, S.R. \& Pimm, S.L. (2009) On population growth near protected areas. PLoS ONE, 4, e4279.

Kato, F. (2007) Development of a major rice cultivation area in the Kilombero Valley, Tanzania. African Study Monographs, 36, 3-18.

Masalu, D. (2000) Coastal and marine resource use conflicts and sustainable development in Tanzania. Ocean \& Coastal Management, 43, 475-494.

Matнвов, G. (2008) Effective Community Participation in Coastal Development. Lyceum Books, Chicago, USA.

Metzger, K.L., Sinclair, A.R.E., Hilborn, R., Hopcraft, J.G.C. \& MDUmA, S.A.R. (2010) Evaluating the protection of wildlife in parks: the case of African buffalo in Serengeti. Biodiversity and Conservation, 19, 3431-3444.

National Bureau of Statistics (2002) Tanzania Population and Housing Census 2002. Http://www.nbs.go.tz/tnada/index.php/ catalog/7 [accessed 21 November 2013].

Nelson, F., Nshala, R. \& Rodgers, W.A. (2007) The evolution and reform of Tanzanian wildlife management. Conservation \& Society, $5,232-261$.

Oglethorpe, J., Ericson, J., Bilsborrow, R.E. \& Edmond, J. (2007) People on the Move: Reducing the Impacts of Human Migration on Biodiversity. World Wildlife Fund and Conservation International Foundation, Washington, DC, USA.

Ostrom, E. (1990) Governing the Commons: The Evolution of Institutions for Collective Action. Cambridge University Press, Cambridge, UK.

Plumptre, A.J. (2000) Monitoring mammal populations with line transect techniques in African forests. Journal of Applied Ecology, 37, 356-368.

R Development Core Team (2012) R: A Language and Environment for Statistical Computing. R Foundation for Statistical Computing, Vienna, Austria.

Sachedina, H. \& Nelson, F. (2010) Protected areas and community incentives in savannah ecosystems: a case study of Tanzania's Maasai Steppe. Oryx, 44, 390-398.

Sarker, A.H.M.R. \& Røskaft, E. (2011) Human attitudes towards conservation of protected areas: a case study from four protected areas in Bangladesh. Oryx, 45, 391-40o.

Scholte, P. \& de Groot, W.T. (2010) From debate to insight: three models of immigration to protected areas. Conservation Biology, 24, $630-632$.

SEn, A. (1983) Poverty and Famines: An Essay on Entitlement and Deprivation. Oxford University Press, Oxford, UK.

ShahabUdDin, G. \& RAo, M. (2010) Do community-conserved areas effectively conserve biological diversity? Global insights and the Indian context. Biological Conservation, 143, 2926-2936.

Silveira, L., JÁcomo, A.T.A. \& Diniz-Filho, J.A.F. (2003) Camera trap, line transect census and track surveys: a comparative evaluation. Biological Conservation, 114, 351-355.

Songorwa, A.N. (1999) Community-based wildlife management (CWM) in Tanzania: are the communities interested? World Development, 27, 2061-2079.

Starkey, M., Birnie, N., Cameron, A., Daffa, R.A., Haddelsey, L., Hood, L. et al. (2002) The Kilombero Valley 
Wildlife Project: An Ecological and Social Survey in the Kilombero Valley, Tanzania. Kilombero Valley Wildlife Project, Edinburgh, UK.

Stoner, C., Caro, T., Mduma, S., Mlingwa, C., Sabuni, G. \& Borner, M. (2007) Assessment of effectiveness of protection strategies in Tanzania based on a decade of survey data for large herbivores. Conservation Biology, 21, 635-646.

Valencia-Sandoval, C., Flanders, D. \& Kozak, R. (2010) Participatory landscape planning and sustainable community development: methodological observations from a case study in rural Mexico. Landscape and Urban Planning, 94, 63-70.

Wittemyer, G., Elsen, P., Bean, W.T., Burton, A.C.O. \& Brashares, J.S. (2008) Accelerated human population growth at protected area edges. Science, 321, 123-126.

\section{Biographical sketches}

ANDREW BAMFORD is an ecologist and conservationist, with an interest in the behaviour and conservation of a wide variety of birds and mammals in Europe and Africa. He studied vultures in southern Africa before undertaking this research in Tanzania, and currently works in Madagascar. Daniella Ferrol-Schulte is researching coastal and marine natural-resource dependent livelihoods on Zanzibar and in Indonesia. Previously she studied the effects of a conservation concession on primate behavioural ecology in the Peruvian Amazon. Jennifer Wathan has a background in psychology and cognitive neuroscience and is researching the social sensitivity of horses, focusing on the evolution and use of facial expressions. 